DOI: $10.17516 / 1997-1370-0033$

УДК 130.2:316.77

\title{
Cultural Meanings of Mediaspace: Philosophical Aspects
}

\author{
Inna V. Vyselko* \\ National Technical University of Ukraine \\ "Kyiv Polytechnic Institute" \\ Kiev, Ukraine
}

Received 07.01.2015, received in revised form 23.01.2015, accepted 10.08.2016

\begin{abstract}
The dynamics of contemporary media culture initiates addressing the problem of cultural meanings study in a transdisciplinary way. This current research is implemented in two areas of philosophical reflection, aesthetic and methodological. The aim of this article is to clarify the specifics of "the cultural meanings" in the philosophical and aesthetic discourse and study the role of media space in the realization, transfer and transformation of cultural meanings. The study focuses on the aesthetic media, which in turn affects the information circulating in the media cultural space. For this research the author incorporated works of scholars such as H. Rickert, W. Benjamin, R. Barthes, O. Pavlova, A. Ruchka in the philosophical discourse of humanities, as these works reveal the mediator importance in the process of transformation of cultural meanings, screen and monitor. Therefore, it affects the media space's cultural discourse: the transformation of values, ideals and cultural meanings.
\end{abstract}

Keywords: cultural meanings, cultural value, media space, virtual reality, aestheticization, media culture.

Research area: history.

Citation: Vyselko I.V. (2019). Cultural Meanings of Mediaspace: Philosophical Aspects. J. Sib. Fed. Univ. Humanit. Soc. Sci., 15(4), 476-484. DOI: 10.17516/1997-1370-0033.

(C) Siberian Federal University. All rights reserved

* Corresponding author E-mail address: vuselka@meta.ua 


\section{Introduction}

Media space, media culture, and other media channels have long been the subject of a wide range of sciences. In the context of philosophical reflection, special attention is paid to aesthetic and axiological aspects of the establishment and functioning of media space as the ultimate determinant of cultural meanings today. Aestheticization of virtual reality takes place in strategic communication practices because, first of all, it eliminates the demand for free embodiment of dreams, illusions of the subject on the choice from the infinite palette of beautiful things, creativity in designing their own reality. The process is how to use artistic means of expression and in-depth and structural transformations of space with the accumulation of both traditional and cultural meanings and find new meanings and values characteristic of the era.

\section{Statement of the problem}

In today's dynamic media world the key problem is the society functioning, as justified by the observed in the information society general trends in media culture. This situation is directly related to the social influence of audiovisual communications and media space in general, resulting in the emergence of a new social reality, which initiates a change of consciousness, the formation and transformation of cultural meanings. Value-semantic perspective, which is directly linked with the dominance of the media segment of society, has by far not investigated enough, since scientists are only beginning to apply a philosophical discourse for the research category of "cultural meanings".

This topic has long remained within the framework of sociology, despite the fact that cultural meanings are inextricably linked with established values and traditions of the aesthetic nature in particular.

The aim of this article is to clarify the specifics of "the cultural meanings" in the context of contemporary philosophical and aesthetic discourses to highlight the features of modern communication (media space orientation) and its role in cultural meanings in the process of aestheticization.
In order to achieve this goal, one should first of all study the works of modern scholars, who have once raised this issue and given special priority to cultural meanings of aesthetic media space.

\section{Theoretical framework}

The study of this problem was initiated by scientists from different fields of knowledge, including philosophy, aesthetics, cultural studies, sociology. Referring to the philosophical and aesthetic context, one must remember about such scientists as W. Benjamin, H. M. McLuhan, N. Luhmann, P. Bourdieu, R. Barthes and neo-classical representatives, namely $\mathrm{H}$. Rickert. In the development of approaches to the problem we should not forget about the significant role of such modern local researchers as O. Pavlova, N. Kostenko, A. Ruchka.

We consider appropriate to follow their understanding and interpretation of the concept of "cultural meanings", values, value paradigms, and civilization's identity of a man and society in a certain historical period. Cultural meanings include a diverse palette of religious beliefs, moral principles, but in a particular culture, they stand out in the array of this culture core values.

\section{Discussion}

The renowned researcher media communication H.M. McLuhan examines the phenomenon of expanding human capabilities by communication means, while modern sociologist N. Luhmann notes that "communication in the art system is the only form of communication that transmits not only the forms of meaning, but also the feeling together with the physical senses" (Luhmann, p. 45). In this context, according to the researchers, media philosophy is as follows: "The history of media implies continuation (extension) of our perceptual capabilities and communication abilities, but with the observation that this growth can not be associated with the body organs' immediate sensations such as touch, smell, hearing" (Savchuk, p. 12). It should be noted that the increase in the range of extension rights that are provided by communication media is not widely accepted 
as they remain out of the media formats concerning listed above body senses.

Therefore, the strategy is interpreted as aestheticization and compensation of complex feelings in the media fullness. Those are more invariant to be artistic culture of media space; their aesthetic range (in the classical sense of the process) is minimal.

The phenomenon of aesthetic culture in the media is laid out in the works of foreign and local researchers. In this context, in order to understand the formation of specific aesthetic space in the media, the researcher O. Pavlova said: "The classical aesthetics had some instructions that have structured its subject area. These included: the autonomy of the aesthetic sphere (especially for the Renaissance art history), self-sufficiency of artistic abilities (D. Hume), the presence of a priori principle of pure reason (I. Kant), free expression of personality in the beautiful (J.C.F. von Schiller), beauty not as an absolute value, but an aesthetic pleasure of life (Romanticism), the justification of aesthetic knowledge as a system within rational-targeted ideas (G. Hegel). A day of total representation of reality by the media means leads to the definition of postmodern culture as "cultural industry" (T. Adorno), "hyperrealist" (R. Barthes), "spectacle society" (G. Debord), "the era of emptines" (G. Lipovetsky). The objective of the study is the argument value mutual aesthetic sphere and the media in the hypostasis which is aesthetically transformed form of the present" (Pavlova). Thus, a new phenomenon is formed, which transcodes aesthetic meanings in the new cultural space. A clear system of art and aesthetic theory of patterns reinterpreted for implementing cultural meanings in the format of virtual reality. Cultural meanings in this context should be interpreted as the various theoretical concepts of classical and modern aesthetics and as the core cultural common values, meanings, ideas and symbols of culture as a way of being human.

Aesthetization of media space is available in various forms. Therefore, the film and television displays information as artistic and documentary or newsreel in a kind of counterpoint Information Network, which dramatizes a narrative and, ironically, transforms it into game and planar screen. Political events garner the coverage through artistic format of presentation: music, staffing, music video installation and entertainment. The media resource aims to create a special aesthetic space in 3D format by using various stereo techniques. Of particular note is the Internet communication via the computer screen, which is also an aesthetic technique: design of web pages, websites, social media, design and presentation of news and more. Aesthetic means building virtual reality can create the illusion of creative actualization of the individual. If art in the classical sense and artistic expression outside the context of media conversion is an act of true reality, the world of media technology, replacing this act with the proposed model of self-identity, which, in our opinion, is directed and realized in the artistic imagination of a recipient because of onscreen culture.

The cultural meaning as the accumulation of experiences, values and principles, ideas and symbols of culture in pre-Information Age was embodied in various forms of consciousness. The strong and representative role is that it reflects the history of art. System of styles, genres and art forms organizes time and spatial continuum in which art imagery represents the dominant meanings of culture, extrapolated from the sphere of religion, morality, politics, and science. This aesthetic design requires skills and willingness of the recipient and professional artist. However, the media space breaks conventional boundaries between an author and a recipient, on the one hand, it creates a new structure of the cultural meanings embodiment through a kind of connotative text, on the other hand, it implies a similar aesthetic design as self-constructing world outside the media cultural space. Therefore, the consumer learns about modern aesthetic principles in the media products through cultural meanings which impose and embody them in our own living space. The goal becomes the tool and vice versa. Media space acts as one of the aims of aesthetic construction of reality. As aqua surf, media slides after returning to the cultural space coast and dehydrate without further waves, so it is doomed to experience drought. Therefore, the aesthetic range of media space 
generates new techniques that are increasingly affecting the representation of consumers and transform reality.

A special technique that we believe deserves special attention is the modern way of aesthetic media space in the form of both destruction and creation of cultural meanings that directly indicate fast fame and recognition for someone who does not agree to "waste" time on professional development and is ready to make several steps to overcome the distance between being unknown and being hyped for their creativity on various TV channels and websites. This glory is both instantly proclaiming and promptly lost. However, the latter remains behind the scenes in the media space.

The Ukrainian media culture, in our opinion, can give many examples of this strategy, including TV projects such as "X-Factor", "Everybody Dance", "Ukraine's Got Talent", and so on. The purpose of these programs is articulated as the search for talents. However, we believe that this is a manipulative strategy to transform cultural meanings. Unlike the traditional way in the profession in those public institutions that are established to teach the skills, in the mind of the recipient there is an idea of the possibility to cut this path, avoid formal training and become a better professional and more popular by the end of the project.

The winners of these projects "taste" fame, go on to participate in other projects or become despondent in their abilities and skills, because their credibility was spent in vain. It is necessary to clarify that we are far from condemning such projects. They are spectacular, get high ratings, and ultimately what sounds from television screens is music. However, we emphasize the substitution of deep meanings that destroy the aesthetic hierarchy of artistic culture and create variety of meanings.

Analyzing the cultural text as space formation of cultural meanings should refer to the concept of text analytics R. Barthes. In order to understand what space the text should introduce such concepts as "codes" proposed by Robert Barto. According to the concept of the researcher codes permeate the cultural text as strings, forming its meaning. The researcher rejects the interpretation of meaning in one sense, since in his opinion it reduces the space of the text and leads to a narrow interpretation of meanings. Text inherent multiplicity: "It means it is not just a few meanings, but that it brings multiplicity of meaning as such, the indestructible multiplicity, not just tolerated. In the text there is no peaceful coexistence of meanings, they cross into their moves through them, so it is not exposed to pluralistic interpretation, it there is an explosion and scattering of meaning" (Barthes, p. 67). Thus, the very multiplicity of meanings understood only through codes and forms the space of the text. Text is inextricably linked and deterministic time-history, culture, meaning, society-man. In general we can say that the production is inextricably text included in the "beyond-text reality" and "symbolic space" (Mikitinets, p. 42).

Referring to studies of audiovisual communication one should recall the scientist W. Benjamin and his work entitled "Works of art in the age of technical reproducibility" in which the researcher described the formation of visual culture. W. Benjamin not only captures the change in a person's world, but also explores how this happens. The researcher tries to answer the question of how the development of technology, i.e. the reproduction of images, affect the human perception of the world, the formation or modification of certain culture-heritage identity as we understand cultural meanings. An interesting phenomenon poses the problem of the uniqueness disappearance.

Any attempt to reproduce an image generating secondary image that alters the interaction between the actor and the reality is the person who is trying to play the objective reality and the environment. The author claimed that "nature, facing the camera is not the nature facing the eye; difference lies primarily in the fact that the place space assimilated by the human mind, taking up space, mastered unconscious" (Benjamin, p. 71). In other words, play the objective reality in all its diversity, or create a double lens using cameras and camcorders impossible because the resulting image will subjective, there is such a thing as a distortion of cultural discourse. The above phenomenon can be interpreted; it does not give a complete picture of the world and not its extension. It should 
be noted that fixing through an intermediary (the objective lens) some point of life, we do not have the whole picture since pulling out pieces of the whole, which is not conducive to creating a complete image, and leads to a distortion of meaning. Undoubtedly, both time and space art basically is the only piece of reality. But after armory art artist through the prism of his philosophical offsetting entry and accumulated cultural meanings in a fiction work.

It provides a potential deployment and perception in its entirety reflection of the world to the recipient. A technical tool, as a mediator of this process, as a mediator of creation and perception does not simply slow and reduce the art content, but actually blocks the opportunity for further existence of art. It should be noted that the views of $\mathrm{W}$. Benjamin are categorical and not shared by all members of aesthetic thought of the $20^{\text {th }}-21^{\text {st }}$ centuries.

Science displays and actively explores contemporary art practice in which the mass media plays a substantial role. Conceptualization of the problem reflects the theory, the reception of which is those that depict the creative potential of modernization. Therefore, transformation of artistic practice and its theoretical reflection take place.

Special attention is given to the problem of cultural meanings and values functioning and formation. The most important part is presented in the media communication, which is the main source of knowledge of the world and a person. Problem of self-identification of rights as part of socialization is related to the audiovisual communication that forms the world view and consciousness of the individual; his/her value orientations and constructs social reality. Cultural meanings are able to perform this fundamental function, namely the function of society integration, maintaining its value and stability (Kostenko).

In our opinion, the concept of "cultural meanings" and "values", and most importantly their existence in the phenomenal field are inseparable and interdependent. Cultural meanings are a phenomenon that involves value orientations of the individual and society as a whole. Values considered in the paradigm of cultural identity, which are formed by means of established cultural meanings in the "core culture" according to the terminology representative of this trend, H. Rickert followed cultural tradition. H. Rickert mentions that "value has a spiritual purpose, vital practical mental setting, expressing nerve of lively culture, its semantic core that reflects the culture dynamics" (Rickert, p. 365).

That is, the values are the result of the functioning of culture and cultural meaning as integral structure and as a culture. Understanding the meaning of meaning requires knowledge of human relationships or certain human groups both in actual life situation in which they are present, and with the life experiences of previous generations or the project of human life and the future (Kostenko).

One should refer to the importance of the individual value orientation. Value orientation is defined as the ratio of sample to a set of material and spiritual values and ideals that are considered as objects of goals and the means to meet the needs of individuals or social groups. Formed in the social practices, values mediate the impact of the environment: they accumulated experience of people. Having established orientation characterizes maturity as human beings, but these orientations are direct lever of influence audiovisual communication, which, in turn, is an active participant in the formation of the individual as a whole, and is an inexhaustible source of information about the world and the cultural world of humanity. Therefore, as a result of human activity, its existence is the formation of certain values, which is primarily due to the existing cultural meanings inherent in society. Therefore, the value orientation is found in human activity as a hierarchy of benefits that a person gives their material and spiritual values (Drach, p. 305).

Since the inception of the society in the first place laid horizons of cultural meanings that are established informal rules of functioning and development of society. Reflection in mythological consciousness ideas about the world and man's place in it, the meaning of life and the inevitability of death and the fate of the hero exploit people and other ethnic characteristics forms meaning and form concentrated on the core of culture and determine the formation 
of cultural meanings. They direct the lives of people, as traditions and values are basic concepts as the cultural meanings are formed a number of legal, moral and ethical standards, which, depending on the policy are binding or not enforced. But in everyday life of each national community of people, some informal rules is imperative, though not enshrined in law. Cultural meanings form the perception of people, the deviation from certain rules considered non-conformist behavior. Broadcast cultural meanings, values and traditions is through communication that has different forms and manifestations (audio, video, or even tactile communication). With the development of $20^{\text {th }}$ century science and technology and progressive trends in media communications, cultural meanings lose their identity, because it is easily transformed and taking on new forms with curvature or distortion of cultural discourse with the help screen (display other forms of communication). In recent years, especially in connection with the intensive development and computer science, and computer engineering, and their active penetration into society are increasingly faced with a highly informative approach to understanding the essence of culture and education. This trend understands the educational process and the process of transmission of knowledge in general as a channel of information from the teacher, a teacher or even automated complex, which in the modern era of information can replace live communication with the user of this information. Hence the rather stable theory which involves the term "information technology teaching", it is the transfer and translation of knowledge is responsible for the establishment and development of individual assimilation of established norms, traditions, customs inherent in a given community cultural meanings and knowledge of the world. So speaking of broadcasting cultural meanings should not forget the importance of education in this process and indepth use of media technologies, which in most cases form the identity of the information age.

Methodological problems in research focus of value and aesthetic understanding of the functioning of cultural meanings media space is interdisciplinary. Since the principle of us- ing strategies in modern integrated approach: ideas, methods and technologies for producing, storing, selective sampling and operational insight to consumers of different types of scientific information can be useful and be required. Any attempt of using information and computer tools to intensify, intensify, ultimately optimize multi-component process of learning, skills, methods of creative activity, not to mention the formation of the whole gamut of human relations to the world and to each other, his outlook, mentality, culture, behavior, Booz certainly deserves detailed study. Media space forms a natural tendency and the need for effective communication. In the context of aesthetic and axiological approach should be noted that the specific media culture is one in which create impression on the following: the main thing is not lost - the emotional character of a full life of people who perceive the information being broadcast, which is based on the appeal (appeal) to the individually unique spiritual world each of them an absolute priority to the uniqueness of the individual. In our opinion, this is one of the most dangerous illusions and disappointments, which is the main simulacrum media culture. Therefore, to a large extent to the problem should be addressed in the value-semantic context.

Unfortunately, today's society is biased media. Cultural meanings and culture as such typologies and dissolved in the media that replicates and promotes the heritage of culture and history. On the one hand by means of audiovisual communication, anyone can read a specific work of art, listen to any musical composition, but often you can also find signs of vandalism and frivolous perception of what he saw or heard. If the ring tone on your mobile phone is a classic song eventually over time it begins to annoy and its sound is often inappropriate and perception of others is shallow and frivolous. Crumbling certain cultural meanings that were put into the product during its creation, the distortion of social reality by means of a computer screen, TV, video and camera lenses constructed new cultural meanings that are not always true. Growing concerns about the culture of the same "one reality" losing self-evident under the pressure of many images that claim to be 
real and increasingly becomes a "negotiable" if on its identification requires someone consent. Generally refers to the legitimization of social media ontology. Since "to be is to be shown on television", as noted by Bourdieu (Bourdieu, p. 205), or to attend, to be present in the world wide web, which is true not only for popular people, but also for any events, occurrences, statuses and styles.

\section{Conclusion}

Thus, aesthetic media space leads to expansion of cultural meanings of modernity within the virtual reality. The principles of media aesthetics, in many respects form polyphony of theoretical approaches and artistic practices aimed at university effect without feedback from the recipient, but imitate updating as the performance in the virtual space of culture. Cultural meanings lost expression through the beautiful, tragic, heroic, etc. and expressed through spectacular music video, fragmented, and thus affect the aesthetic presentation of the recipient. The reality of media space provides the aesthetic experience of the subject in those key parameters aesthetic in which this development has commercial appeal. Aesthetic reduced to a bright, pleasant consolation. Virtual reality is no longer a feature of the real and the imaginary, because, being a virtual reality affects both aesthetically and in value-semantic dimensions.

It should also be noted that the axiological characteristics of cultural meanings are signs of transformation. The value system of higher goals, ideals realized in a culture is destroyed. They offered to replace and axiological trend that can be called, the value of freedom and choice. However, it is this value system is eliminated, as in the forms of new cultural meanings, mechanism becomes manipulative media culture. We believe that the value of freedom, the right to choose the immensity of information - values is an illusion media space, which are actually determined manipulative strategies of mass communication.

\section{References}

Barthes, R. (1989). Ot proivedeniia k tekstu. Izbrannye raboty. Semiotika: Poetika [From the work to the text. Selected works. Semiotics: Poetics]. Moscow, 413 - 424.

Benjamin, W. (1996). Raboty iskusstva v epohu ego tehnicheskoy vosproizvodimosti. Izbrannyie esse [The work of art in the age of mechanical reproduction. Selected essays], ed. by Yu.A. Zdorovyi. Moscow, Medium, $302 \mathrm{p}$.

Bourdieu, P. (2002). O televideniie $i$ zhurnalisme [About TV and journalism]. Moscow, $405 \mathrm{p}$.

Deleuze, G. (1995). Logika smysla [The Logic of Sense]. Moscow, Academy, 302 p.

Drach, G.V. (2003). Kratki kulturologicheskiy slovar [Brief encyclopedic dictionary]. Rostov-on-Don, $345 \mathrm{p}$.

Frankl, V. (1990). Chelovek v poiskah smysla [Man's Search for Meaning]. Moscow, 366 p.

Habermas, J. (2008). Problema ponimaniia smysla $v$ sotsial'nykh naukakh [The problem of understanding meaning in socia sciences], 7, 3, 3-33.

Khrenov, N. (2006). Spectakli v epokhu vosstaniia mass [Performances in the era of mass rebellion]. Moscow, $646 \mathrm{p}$.

Kostenko, N. (2010). Nastich' real'noe, kogda media povsiudu: ontologicheskii interes kul'turnykh issledovanii teorii i media [Reach real, when the media is everywhere: ontological interest in the culture studies concerning theories and media], In Sotsiologiia: teoriia, metody, marketing [Sociology: theory, methods, marketing], 1, 3-15.

Kostenko, N. (2010). Smyslovaia segmentatsiia sotsiuma [Sense segmentation of the society]. In Ukraiynsyke suspilystvo, Sotsiologichniy monitoring. Kyiv, 254-260.

Kostenko, N. (2011). Znanie o smyslah: issledovanie glubiny i poverkhnosti [Knowledge about meanings: research of the depth and surface], In Sotsiologiia: teoriia, metody, marketing [Sociology: theory, methods, marketing], 4, 1-27. 
Kostenko, N. (2012). Smyslovaia morfologiia sotsiuma [Social morphology of the society]. Kyiv, Institut sotsiologiyi NAN Ukrainy, $422 \mathrm{p}$.

Kostenko, N., Ruchka, A. (2008). Media. Demokratiia. Kul'tura [Media. Democracy. Culture]. Kyiv: Institut sotsiologii NAN Ukrainy, 133-153.

Lall, D. (2002). Mass media, kommunikatsiia, kul'tura: global'nyi podkhod [Mass media: communication, culture: global approach]. Kyiv, 25-85.

Luhmann, N. (2005). Media kommunikativnaia [Media communicating]. Moscow, 467 p.

Masterman, L. (1993). Obucheniye iazyku sredstvami massovoi informatsii [Teaching a language by the means of media]. Moscow, 22-23.

McLuhan, H.M. (2003). Ponimanie media: vneshnie rasshireniya cheloveka [Understanding Media: The Extensions of Man]. Moscow, $453 \mathrm{p}$.

Mikitinets, O.I. (2008). Roland Barthes: tekstual'naya osmyslennost' prostranstva [Roland Barthes: textual meaningfulness of space], In Uchenie Tavricheskogo natsional'nogo universiteta imeni V.I. Vernadskogo. Seriia Philosophiia. Sociologiia, 21 (60), 1, 15.

Pavlova, O. (2008). Naslidki estetizatsii diysnosti: vzayemovpliv estheticy media praktiky v transformatsiyah post suchasnoyi kul'turi, In Visnik Dnipropetrovsykogo universiteta Politologiia [Bulletin of Dnipropetrovsk University. Political sciences], Dnipropetrovsk, 2, 16-23.

Pocheptsov, G. (1999). Teoriia komunikatsii [Communication Theory]. Kyiv, 308 p.

Razlogov, K. (1992). Illiuzii narusheny. Politizatsiia zapadnogo ekrana [Collapsed illusion. Politicization of western screen]. Moscow, $467 \mathrm{p}$.

Razlogov, K. (2005). Audiovizual'naia kul'tura. Novye audiovizual'nye tekhnologii [Audiovisual culture. New audiovisual technology]. Moscow, 15-24.

Razlogov, K.E. (2010). Iskusstvo ekrana: ot sinematografa do interneta [Cinema art: from cinematograph to internet]. Moscow, 287.

Rikkert, H. (1998). Science Nature and Science o kul'ture. Moscow, 365.

Ruchka, A. (2008). Status Ruchka i funktsii media in suchasnomu suspilystvi. Media. Demokratiia. Kul'tura [Media. Democracy. Culture], Kyiv,11-30.

Savchuk, V.V. Mediafilosofiia. Osnovnye problemy i poniatiia [Media Philosophy. Basic issues and notions], In Materialy internatsionalnoi konferentsii. Media object kak philosophiia [Proc. of Int. Conf. Media object as philosophy], 346, Saint-Petersburg.

Sheykin, A. (1997). Smysly kul'turnye. Kul'turologiia XX veka [Culture meanings. Culture studies in the $20^{\text {th }}$ century]. Moscow, $428 \mathrm{p}$.

Sorokin, P. (2000). Sotsial'naia kul'turnaia dinamika: Issledovanie izminenii v bol'shikh systemakh iskusstva istiny, etiki, prava i estestvennykh nauk [Social cultural dynamics: study of changes in big systems of art of truth, law and natural sciences]. Saint-Petersburg, $1176 \mathrm{p}$.

Ursula, A. D. (2010). Priroda informatsii: filosofskoe esse [Nature of information: a philosophical essay]. Chelyabinsk, $231 \mathrm{p}$.

Ishtuk, S.M. (2008). Internet-komunikatsiia: informatsionnyi smysl i igrovoi kharacter [Internetcommunication: information meaning and game character], In Visnik of NAU: Filosofiia. Kul'turologiia [NAU Bulletin. Philosophy. Culture Studies], 2 (8), 87-91. 


\title{
Культурные смыслы медиапространства: философский аспект
}

\author{
И.В. Выселко \\ Национальный технический университет Украинь \\ «Киевский политехнический институт» \\ Украина, Киев
}

\begin{abstract}
Аннотация. Динамизм развития медиакультуры современности инициирует постановку проблемы по изучению культурных смыслов в трансдисциплинарном векторе. В тексте данной статьи это воплощается в двух направлениях философской рефлексии: эстетическом и аксиологическом. Целью данной статьи является выяснение специфики актуализации «культурных смыслов» в контексте философскоэстетического дискурса, а также исследования роли медиапространства в процессе функционирования, трансляции и трансформации культурных смыслов. В исследовании концентрируется внимание на эстетизации медиа, что, в свою очередь, влияет на информацию, циркулирующую в медиаканальном пространстве культуры. В контексте исследования авторы приобщают к философскому дискурсу гуманитаристики статьи и труды таких ученых, как Г. Риккерт, В. Беньямин, Р. Барт, О. Павлова, А. Ручка, раскрывающие посредничество в процессе трансформации культурных смыслов, экрана и монитора. Как следствие, это влияет на культуротворческий дискурс пространств: трансформацию ценностей, идеалов, культурных смыслов.
\end{abstract}

Ключевые слова: культурные смыслы, культурная ценность, медиапространство, виртуальная реальность, эстетизация, медиакультура.

Научная специальность: 07.00.00 - исторические науки. 